\title{
Lovas szolgáltató létesítmények összehasonlító elemzése az Észak-alföldi régióban
}

\section{Comparative Analysis of Equestrian Facilities in the North Great Plain Region}

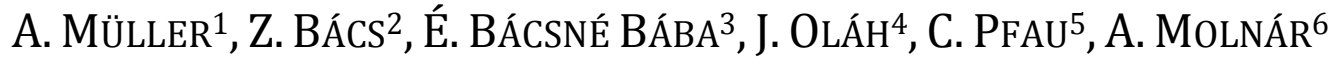 \\ ${ }^{1}$ Debreceni Egyetem, Gazdaságtudományi Kar, Sportgazdasági és -Menedzsment Tanszék, \\ muller.anetta@econ.unideb.hu \\ ${ }^{2}$ Debreceni Egyetem, Gazdaságtudományi Kar, Számviteli és Pénzügyi Intézet, bacs.zoltan@fin.unideb.hu \\ ${ }^{3}$ Debreceni Egyetem, Gazdaságtudományi Kar, Sportgazdasági és -Menedzsment Tanszék, \\ bacsne.baba.e@econ.unideb.hu \\ ${ }^{4}$ Debreceni Egyetem, Agrár Kutatóintézetek és Tangazdaság, Debreceni Tangazdaság és Tájkutató Intézet, \\ olahja@agr.unideb.hu \\ ${ }^{5}$ Debreceni Egyetem, Gazdaságtudományi Kar, Sportgazdasági és -Menedzsment Tanszék, \\ pfau.christa@econ.unideb.hu \\ ${ }^{6}$ Debreceni Egyetem, Gazdaságtudományi Kar, Sportgazdasági és -Menedzsment Tanszék, \\ miller.e.annie@gmail.com
}

Absztrakt. A lovas szolgáltatások megjelennek a rekreációban, sportban és a turisztikai kínálatban egyaránt. Hazánk kedvező természeti és kulturális értékei, valamint lovas hagyományaira építő lovas nemzet imázsa kedvezó hátteret biztosít a kínálati elemek fejlesztésére. Az Észak-alföldi régió alföldi karakterü tája és lovas-kultúrája, az itt található lovas szolgáltatások folyamatos fejlesztése erôsíti a lovas kínálati elemet a sport és szabadidôgazdaság területén. Mélyinterjús kutatásunkat az Észak - alföldi régióban müködő patkós minősítettséggel rendelkező és nem rendelkező szolgáltatók (N=11) körében végeztük. Az eredmények azt igazolják, hogy valamennyi szolgáltató fontosnak véli és tervezi a lóállomány, az infrastruktúra és a humánerőforrás fejlesztését, bár ennek finanszírozásának forrása eltérő (állami, más sikeres vállalkozásból, lovas vállalkozás realizált üzleti eredményébőll). A patkós minősítéssel nem rendelkező lovas szolgáltatók a minőség fejlesztését, a 3, 4, 5 patkós minősitéssel rendelkező szolgáltatók a komplex programkínálat bővítését, a termékdiverzifikációt jelölték meg.

Kulcsszavak: ló, lovas szolgáltatás, lovas turizmus

Abstract. Equestrian services appear in recreation, sports and tourism as well. The favorable natural and cultural values of Hungary and the image of the equestrian nation based on the traditions of the horse provide a favorable background for the development of supply elements. The lowland character and horse culture of the Northern Great Plain region, and the continuous development of horseback riding services here, reinforces the equestrian supply element in the field of sport and leisure. Our in - depth interviews were conducted among service providers with a "horseshoe rating" ( $N=11$ ) operating in the Northern Great Plain Region. The results show that all service providers consider and plan the development of equine, infrastructure and human resources, although the source of 
International Journal of Engineering and Management Sciences (IJEMS) Vol. 4. (2019). No. 3

DOI: 10.21791/IJEMS.2019.3.8.

its financing is different (from state, other successful businesses, realized business results of equestrian enterprises). Equestrian service providers with no horseshoe rating have identified the improvement of quality, the 3, 4, and 5 horseshoe qualified service providers for the expansion of the complex program offering and product diversification.

Keywords: horse, equestrian services, equestrian tourism

\section{Bevezetés}

Turisztikai irányjelzések igazolják, hogy napjainkban a passzív üdülések helyett egyre inkább az aktív szabadidős tevékenységek kerülnek előtérben, melyek a rekreációban és a turizmusban is egyre nagyobb szerepet játszanak [19]. Az aktív turisztikai típusok során célszerű az üdüléseket valamilyen sportág gyakorlásával vagy elsajátításával tölteniük, ami az egészség megőrzéséhez, a képességek fejlesztéséhez, új ismeretek elsajátításához és az élményszerzéshez egyaránt hozzájárul. A lovas turizmus, mint aktív turisztikai típus hazánkban valamennyi régió turisztikai kínálatában megjelenő termék. Népszerűségét adja, hogy az emberek vágyódása a lóhoz ősi, szinte ösztönös, valószínű azért, mert a ló és az ember története szorosan összefonódott. Őseink eleinte, mint vadászzsákmányt követték a vad méneseket, majd a ló élelemforrásból rövidesen „közlekedési eszköz” lett. Az emberek felimerték, hogy a lóhátról történő vadászat lényegesen gyorsabb, és ezáltal egyre nagyobb terület vadászata vált lehetővé. Kezdetektől fogva nélkülözhetetlen volt a hadászatban, mivel a ló hátán ülő ember számára megszűnt a távolság, a harci cselekményekben különböző terepviszonyok mellett is gyorsan és hatékonyan mozgott. Igaz, hogy az iparosodással, a haditechnika fejlődésével, a robbanó motor feltalálásával és a vasúthálózat terebélyesedésével a ló kiszorult korábbi, nagyon jelentős használati területekről. De az emberek szívében a gépek és motorok soha nem tölthetik be azt a helyet, amit a lovak foglaltak el. A megváltozott használatban és értékrendben manapság a lovakat leginkább sportolás és szabadidős lovaglás céljából tartják, de ezeken túl akár a terápiában vagy a turizmusban is eredményesen alkalmazzák [12]. Napjaink aktív turisztikai kínálatában ló- és a lovas szolgáltatások turisztikai termékként jelennek s a termékfejlesztés a lovas programok és szolgáltatások körének bővítése és a szabadidős és turisztikai kínáltban vonzerőtényező és a versenyképesség fontos eleme. A turisztikai és szabadidős tevékenységek módosuló irányai jelzik, hogy a természetben történő kikapcsolódás egyre fontosabbá válik a fogyasztói keresletben, amibe a lovas sportok és lovasturisztikai kínálati elemek igen jól beleillenek. Növekszik az emberekben a múltba veszett életformák megismerésének szándéka, sőt a természettel való szoros kapcsolat kialakításának igénye is, aminek egyik mutatója a városi létből való menekülés vissza a természetbe.[4][5].

\section{Szakirodalmi áttekintés}

Nemzetközi kutatások szólnak a lovas turizmus tipológiájáról és értelmezéséről. Több szakirodalom kiemeli, hogy a lovasturizmust, mint terméket gyakran a falusi, farm vagy vidéki turizmushoz társítva jelenítik meg, hiszen, a vidéki életformához köthetően sok esetben mezőgazdasági vagy agrár területen működő vállalkozások hozzák létre [15][23]. A kalandturizmushoz is igen gyakran társítják a lovasturisztikai terméket, mivel a terep- és túralovaglás változatos természeti értékek között 
különleges élményt biztosít. A rekreáció vagy szabadidőipar részeként is definiálható, melyben a természeti sportok szerepe növekszik, így a lovas szolgáltatásoké is.

Európa rendelkezik a legtöbb lovas turisztikai szolgáltatással. A lovasturizmus piacán hazánk versenytársai: Írország, Spanyolország, Portugália és Nagy-Britannia [18].

Németh [22] megerősíti, hogy a lovasturizmushoz kedvezők a hazai adottságok, mint a lovas hagyományok, a humánerőforrás, a földrajzi terepviszonyok, a lóállomány. A létesítmények színvonala kapcsán, a minőségi kínálatfejlesztést és a marketingkommunikáció erősítését fogalmazza meg fejlesztési prioritásként. A nemzeti vágta, igen jó turisztikai látványosságnak bizonyult, hiszen 2008 óta növekvő érdeklődés mutatkozik iránta közvetlenül a helyszínen, de tv közvetítések által az ország lovasturisztikai imázsát tovább erősíti, [29]. A lovas turizmus területén is fontos a marketing és desztinációmenedzsment, mely a régió vagy az ország lovasturisztikai imázsát erősítheti [14].

Más kutatások a lovas turizmust a vidéki térségek fejlesztés egyik eszközeként értelmezik és mutatják be [18][24][25], amely jó lehetőséget kínál az elmaradt térségek felzárkózására. A Lovasturizmus Fejlesztési Stratégia [18] szerint a hazai kedvező adottságokon túl a hazai aktív kínálatából a lovastúrák és a vadászlovaglás (bár szűk szegmenst elégít ki) a legnépszerúbbek a nyugateurópából érkező vendégek számára.

Az Észak-alföldi régió Stratégiai Programja [2] a régióban a rendezvényturizmus fejlesztését és a hagyományőrzést kiemelten kezeli, amelyben a lovas hagyományok ápolására alkalmas lovasnapokat is nevesíti. A vidéki térségekhez-falusi turizmushoz jól társítható természeti értékekre alapozott lovasturizmus feltételrendszerének fejlesztése- szintén célként jelenik meg. Az Észak-alföldi régió turizmusfejlesztési stratégiája a régió jövőképének a Komplex turisztikai kínálattal rendelkező régió," vízióját fogalmazza meg, amelyben a turizmus fontos húzóágazat" [13]. Ebben a stratégiában a lovas turizmus, illetve annak kínálati elemeinek fejlesztése a falusi turizmushoz, az örökségturizmushoz, az ökoturizmushoz, sportturizmushoz és rendezvényturizmushoz társítva jelenik meg.

Az Észak-alföldi régió lovasturisztikai kínálatában a lovardák biztosítják az aktív és a passzív lovasturisztikai szolgáltatásokat. A hatósági engedéllyel rendelkező lovas szolgáltatók az Észak-alföldi régióban összesen 50-re tehető, melyből 12db Jász-Nagykun-Szolnok megyében, 13db Hajdú-Bihar megyében, és 25db található Szabolcs-Szatmár-Bereg megyében [16]. Az 50 szolgáltatóból 40 db minősített, azaz patkós besorolású. Három lovarda rendelkezik 1 patkós, kettő darab 2 patkós, huszonhat darab 3 patkós, hat darab 4 patkós minősítéssel. A legmagasabb szolgáltatási színvonalat az 5 patkós lovasszolgáltató reprezentálja, amelyből kettő darab van a régióban. Az egyik a Mátai Ménes (Hortobágy), a másik az Újmajori Szabadidőpark (Nyíregyháza). A Jász-Nagykun-Szolnok megyében található, alkalmassági vizsgát tett 73 ló, a megye átlagos lólétszámát szolgáltatónként 6 lóra emeli. Hajdú-Bihar megyében 82 alkalmassági vizsgával rendelkező lóval működnek a szolgáltatók, amely lovardánként átlagosan 6,3 lovat eredményez. Ezekkel az adatokkal mindkét megye elmarad a 19 megyére számolt átlagos 7,1-es lólétszámtól. A legtöbb lovardával és lóval rendelkező Szabolcs Szatmár Bereg megyében 196 alkalmassági vizsgát tett ló található, ami szolgáltatónként 7,84 lovat jelent [16]. 
A régióban Hajdú-Bihar megyében 5, Jász-Nagykun-Szolnok megyében 6, Szabolcs-Szatmár-Bereg megyében 10 található. A turisztikai szezon kitolását segítő fedeles lovardák fontos kínálati elemek a régióban, hiszen a turisták vagy a helyi lakosok számára egész évben elérhetővé teszik a lovas szolgáltatásokat. Lovasoktatásra jogosult személyek száma a régióban 104 fô volt (lovasszakember) így az 50 szolgáltatóra átlagosan két szakember jut.

Az Észak-alföldi régió kínálati elemei alapján (mint a terület gazdag lovas hagyománya és öröksége, természeti értéke), a lovas-turizmus kedvezőnek értékelhető, azonban a hazai és a nemzetközi lovasturisztikai piacon való versenyképesség megtartásában a térség további infrastrukturális fejlesztése elengedhetetlen. Ehhez társulnia kell a lóállomány és humán erőforrás fejlesztésének is.

lovasturisztikai kínálat elemei: létesítmények, lóállomány, hr

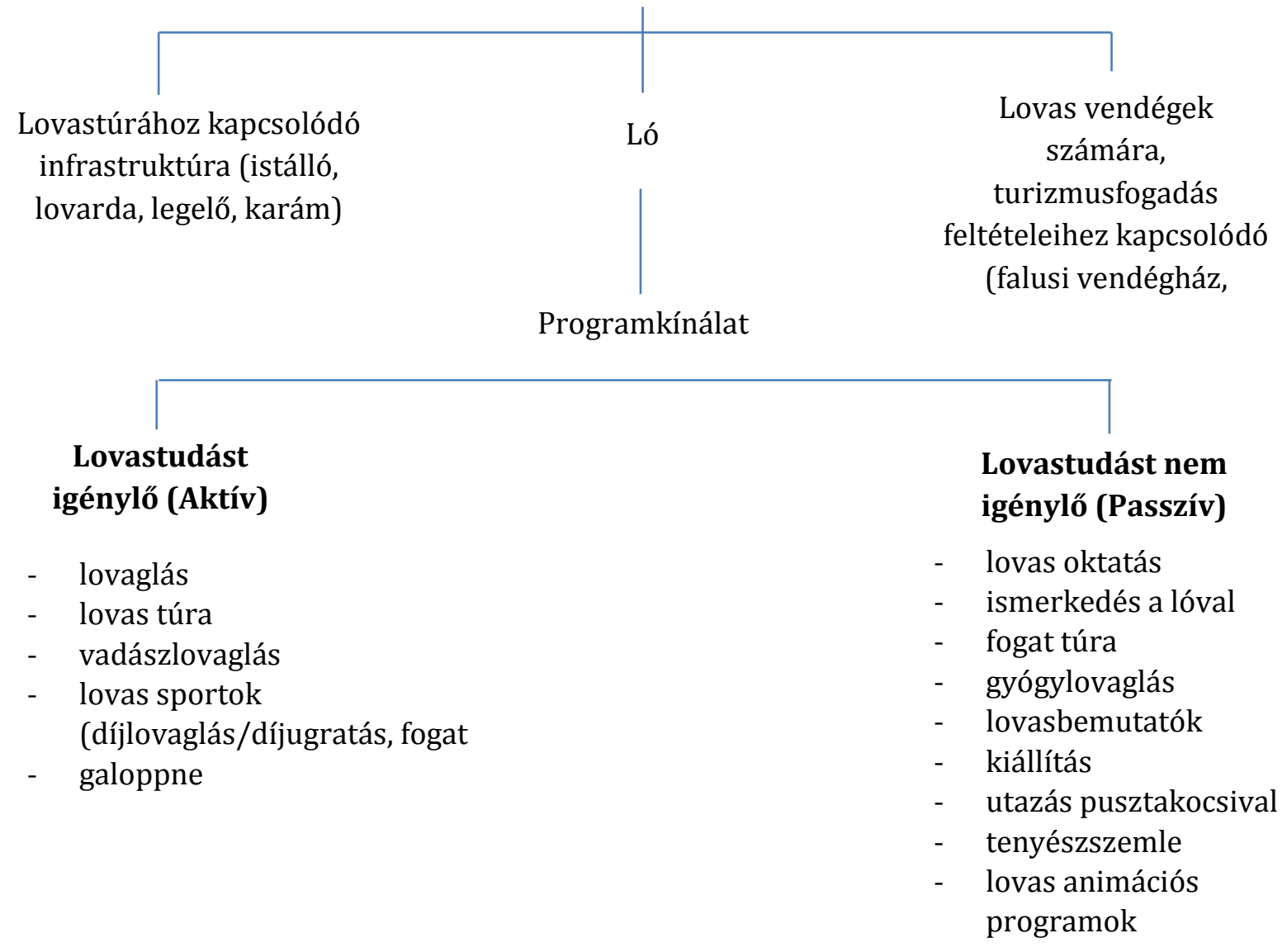

1. ábra: A lovas turisztikai kínálat elemzése 


\begin{tabular}{|c|c|c|c|}
\hline \multicolumn{4}{|c|}{ CÉLCSOPORT } \\
\hline$\Gamma$ & $T$ & $T$ & 7 \\
\hline $\begin{array}{l}\text { Lókedvelők } \\
\text { - véletlenszerű } \\
\text { megjelenés } \\
\text { - laikus turistatömeg a } \\
\text { lovas kínálat iránt } \\
\text { érdeklődőknek } \\
\text { - lovas program, csak } \\
1 \text { turisztikai program } \\
\text { a sok közül } \\
\text { - nem rendelkeznek, } \\
\text { vagy csekély } \\
\text { lovastudással } \\
\text { rendelkeznek }\end{array}$ & \begin{tabular}{l}
\multicolumn{1}{c}{ Lovasok } \\
- tudatosan, \\
célirányosan \\
keresik a lovas \\
szolgáltatásokat \\
- szakértők \\
- legszúkebb \\
szegmens, akik \\
részt vesznek a \\
lovak adásában és \\
vételében is, és az \\
igényes \\
szolgáltatást
\end{tabular} & $\begin{array}{l}\text { Hobbilovasok } \\
\text { - ôk a tipikus } \\
\text { lovas vendégek } \\
\text { - lovastudással } \\
\text { rendelkeznek } \\
\text { - tudatosan } \\
\text { keresik a } \\
\text { lovasszolgáltat } \\
\text { ásokat }\end{array}$ & $\begin{array}{l}\quad \text { C.saládok } \\
\text { - a lovas szolgáltatás } \\
\text { csak 1 program a sok } \\
\text { közül } \\
\text { - } \text { többféle lovas } \\
\text { szolgáltatás iránt } \\
\text { érdeklődnek } \\
\text { - } \\
\text { gyerekeknek szóló } \\
\text { programok }\end{array}$ \\
\hline
\end{tabular}

2. ábra: A turisztikai kereslet elemzése, Könyves - Müller 2001 alapján

\section{Anyag és módszer}

Kutatásunkat az Észak-alföldi régióban tevékeny lovas(turisztikai) szolgáltatók körében végeztük. A szolgáltatókat úgy választottuk ki, hogy mind a 3 megyéből képviseltessék magukat a mintában, valamint, hogy többféle minőségű szolgáltató is elemezve legyen (patkós és nem patkós). Mélyinterjús kutatás során arra kerestük a választ, hogy az Észak-alföldi régióban működő szolgáltatók

- milyen aktív és passzív lovasturisztikai szolgáltatások kínálnak?

- milyen fejlesztési prioritásaik vannak?

- kik a főbb célcsoportjaik?

- melyek a legnépszerübb szolgáltatások?

- hogyan érik el a célcsoportjaikat?

○ hagyományos marketingkommunikációs eszközökkel?

○ inkább az online lehetőségeket részesítik előnyben?

Az eredmények értékelése után célunk volt a szolgáltatók csoportosítása, ami segítségünkre volt a különböző kínálati elemekkel, célcsoporttal, árbevétellel rendelkező szolgáltatók értékelésében és a további fejlesztési rangsorok meghatározásában.

A szolgáltatók értékelésénél 2 fő csoport között tettünk különbséget. A magyarországi lovasturisztikai szolgáltatásokat nyújtó létesítmények minősítésére a Magyar Lovas Turisztikai Szövetség kezdeményezésével, a Magyar Szabványügyi Testület által létrehozott patkós minősítési rendszert alkalmaztuk [17]. A rendszer 2001-ben került bevezetésre, és a következő főbb minősítési szempontok alapján értékel. 


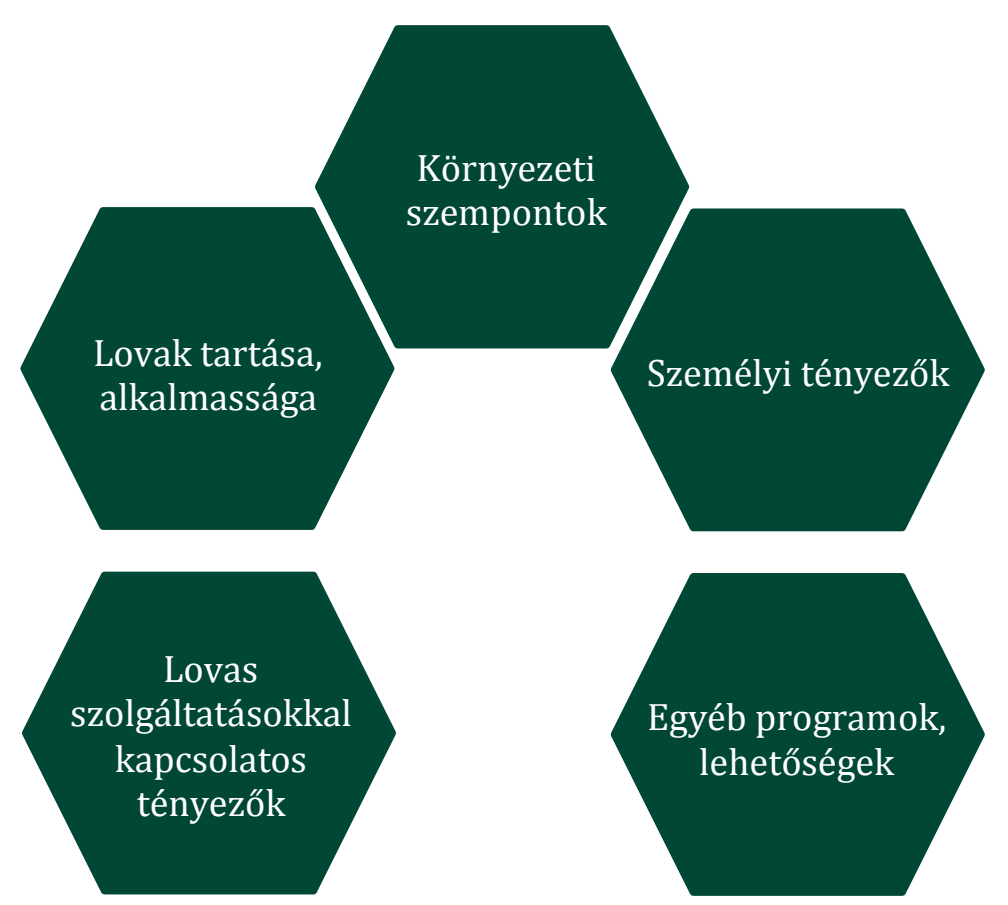

3. ábra: Főbb minősítési szempontok

A környezeti szempontoknál a lovas szolgáltatások nyújtására használt terület alkalmasságát, higiéniás feltételek biztosítását, a létesítmény által működtetett épületek állapotát, a környezet rendjét és parkosítását, illetve a természeti adottságokat minősítik.

A lovak tartásával és azok alkalmasságával kapcsolatos feltételeknél elsősorban a lovak egészségügyiés kondicionális állapotát mérik, ezen felül a tartástechnológiai körülmények is górcső alá kerülnek. Mivel a lovak, mint a szolgáltatás nyújtásának eszközeiként jelennek meg, ezért elengedhetetlen azok képzettségi fokának, kezelhetőségének és az emberhez való viszonyulásának felmérése is. Ezeken felül elengedhetetlen a szolgáltatásnak megfelelő alkalmasság vizsgálata is.

A létesítmény környezete, és az állatokkal kapcsolatos szempontok minősítése után következik a lovas szolgáltatásokkal kapcsolatos elvárások értékelése. Ebben a kategóriában pontozzák a szolgáltatások körét és színvonalát, azok ár-érték arányát. A létesítményhez tartozó szerszámok megfelelő számát, tisztaságát, kényelmességét és biztonságát. Ebbe a kategóriába kerül minősítésre a hely marketingkommunikációja is.

A negyedik főbb minősítési szempont a személyi tényezők bírálása. Alpontjaihoz tartozik a lovas szakember, azaz a vezető, illetve a szolgáltatást végző személyzetek alkalmassága, a szakképzettség, nyelvtudás. Balesetmegelőzés, védelem, biztonság.

A konkrét lovasturisztikai elemek minősítése után vizsgálatra kerül az egyéb programok és lehetőségek tárháza is. A helyi és a létesítményen kívüli programlehetőségek, az állandó rendezvények és látványosságok, illetve a vendéglátóipari és szálláslehetőség osztályozására kerül sor a kategórián belül. 
5 különböző minősítési kategóriát differenciálnak. A fentebb említett szempontok 1-től 5-ig terjedő pontozással vannak értékelve. A fő szempontok pontszámai pedig az alszempontok értékeiből tevődnek össze. Ezen pontozásos rendszer alapján a létesítmények 1 patkótól, 5 patkóig terjedő minősítést kaphatnak, A regisztrált (engedélyezett) szolgáltatók közül nem kaptak patkós minősítést azok, amelyek a szolgáltatás alacsony színvonala miatt, vagy újonnan alakulásuk okán, esetleg újabb beruházás, vagy átépítés végett nem voltak minősíthetők [17].

\begin{tabular}{|lccccc} 
& $\begin{array}{c}\text { 5 fő szempont } \\
\text { átlagpontszáma } \\
\text { egyenként }\end{array}$ & $\begin{array}{c}\text { Szolgáltatásban } \\
\text { résztvevő lovak } \\
\text { száma }\end{array}$ & $\begin{array}{c}\text { Szolgáltatás- } \\
\text { típusok száma } \\
\text { (min.) }\end{array}$ & $\begin{array}{c}\text { Kötelező } \\
\text { idegen } \\
\text { nyelvtudás }\end{array}$ & Pontszám \\
\hline 5 patkós & $>4$ & $>10$ & $>3$ & + & $22-25$ \\
\hline 4 patkós & $>3,8$ & $>8$ & $>3$ & + & $19-21$ \\
\hline 3 patkós & $>3,4$ & $>5$ & $>2$ & + & $17-18$ \\
\hline 2 patkós & $>3$ & $>4$ & $>2$ & + & $15-16$ \\
\hline 1 patkós & $>2,4$ & $>3$ & $>1$ & + & $12-14$ \\
\hline
\end{tabular}

1. táblázat: A minősítés besorolásának objektív paraméterei

\section{Eredmények}

Tanulmányunkban 11 az Észak-alföldi régióban működő lovas szolgáltatót vizsgáltunk, s ezeket a hivatalos patkós minősítési rendszer alapján 2 fő csoportra osztottuk. Először is összehasonlítottuk a minősítéssel nem rendelkező, ezt követően pedig a 3, 4 és 5 patkós létesítményeket.

Az eredmények értékelése során kiderült, hogy sokszínűségük miatt nagyon nehéz a különböző szolgáltatókat összevetni és értékelni. Nem csak a szolgáltatások minősége (patkós vagy különböző minősítésű patkós), hanem a vállalkozás finanszírozása és a múködtetési formája is eltérő. Ezen szempont szerint megkülönböztethetünk:

\section{1. Állami fenntartású lovas létesítmények}

A vizsgált szolgáltatók között ilyen a Hortobágy-Máta, az országban egyébként a Mezőhegyesi Állami Ménesbirtok és Tangazdaság, a Szilvásváradi Állami Ménesgazdaság, Bábolna Nemzeti Ménesbírtok hasonló lovas szolgáltatói típust jelent. Fő jellemzője, hogy állami tulajdonban lévő, így nagyfokú állami támogatásban részesül, de a fejlesztés és fenntartás költségét vállalnia kell és árbevétel is kötelezettek. A feladatkörében azonban megjelenik az értékes magyar lófajták genetikai állományának megőrzése, a lótenyésztés és fajtafenntartás feladatköre. Természetesen itt is megtalálhatóak a komplex lovasturisztikai szolgáltatások.

\section{Személyes indíttatású lovas szolgáltatók}

Azokat a szolgáltatókat soroltuk ebbe a csoportba, akik más sikeres vállalkozásból invesztálnak nagyobb összeget a lovas létesítmény beindításához és annak üzemeltetéséhez. Kevésbé érzékenyek a kereslet változására, mivel más forrás is rendelkezésre áll annak üzemeltetésére. Ezeknél a szolgáltatóknál a komplex kínálat megjelenítésére való törekvés, a minőségi fejlesztés, a termék sokszínűség jelen van a fejlesztési koncepcióban.

\section{Főfoglalkozású lovas szolgáltatók}


Ebbe a csoportba kerültek azok a szolgáltatók (vállalkozók), akik számára a lovas szolgáltatás, megélhetési formaként jelenik meg. Az értékelés szerint esetükben a fenntartás és a nyereséges üzemeltetés nehézségekbe ütközhet. Akkor tudnak eredményesek lenni, ha mezőgazdasági tevékenységet is folytatnak, megtermelik az állatok takarmányát, szolgáltatásuk a turistafogadás feltételeinek biztosítására is (szálláshely, étterem stb.).

\subsection{Interjúk kiértékelése}

A szolgáltatók anonimitásának megtartása érdekében tanulmányunkban nem nevezzük meg a létesítményeket, ehelyett az egyszerübb és átláthatóbb beazonosítás érdekében a magyar ábécé nagy kezdőbetűit rendeltük bizonyos létesítményekhez. Mélyinterjúnk bevezető kérdésében arra kértük a szolgáltatók képviselőit, mutassák be röviden a létesítmény alapításának történetét, mikor alakultak, milyen indíttatással, háttérismeretekkel és ösztönző erővel rendelkeznek. Az eredményeket a 4. sz. ábra foglalja össze.

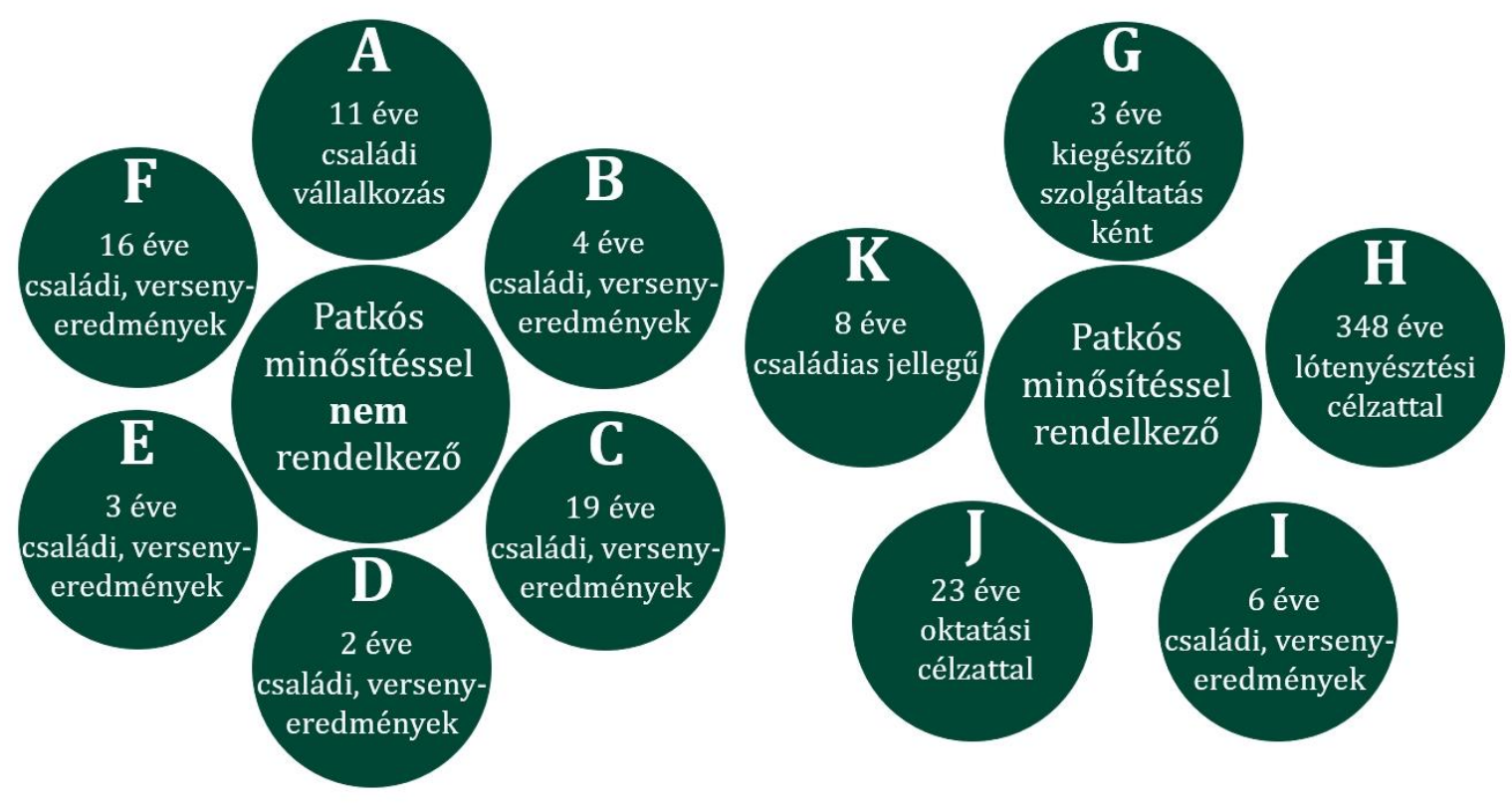

4. ábra: A létesítmények alapításának rövid ismertetése (mikor alapították, milyen indíttatással)

A létesítmények alapítása és a működési idejük alapján a vizsgált szolgáltatókról változó kép tárult elénk. A minősítéssel nem rendelkező alanyok fele csupán néhány éve alakult, fiatal vállalkozás. Ma még nem rendelkeznek a minősítés megszerzéséhez szükséges feltételekkel.

A 4 és 5 patkós szolgáltatók mindegyike gazdag történeti háttérrel rendelkezik, többnyire patinás létesítmények. Létezésük hosszú évei során magasabb minőségű szolgáltatás nyújtását megteremtő fejlesztéseken és terjeszkedéseken mentek keresztül. Igényes fogyasztói (vásárlói) körük van.

A vállalkozások indításának motivációi között nem figyelhető meg jelentős különbség a minősítéssel rendelkező és nem rendelkező szolgáltatók között. Szinte mindegyik vizsgált szolgáltatás alapítói valamilyen lovas sporthoz kapcsolódó háttérismerettel rendelkeznek, legyen szó Nemzeti Vágtán 
megnyert versenyről, mezőgazdasági, azon belül is lótenyésztéshez kapcsolódó végzettségről, vagy különböző lovasszakági versenyzői múltról. Kijelenthető, hogy lovas turisztikai központjuk nem csupán a nyereségszerzési célon alapult, s mindegyiküknél közös pontnak számított a lovak szeretete. Többen vállalkozásuk családias jellegéről nyilatkoztak.

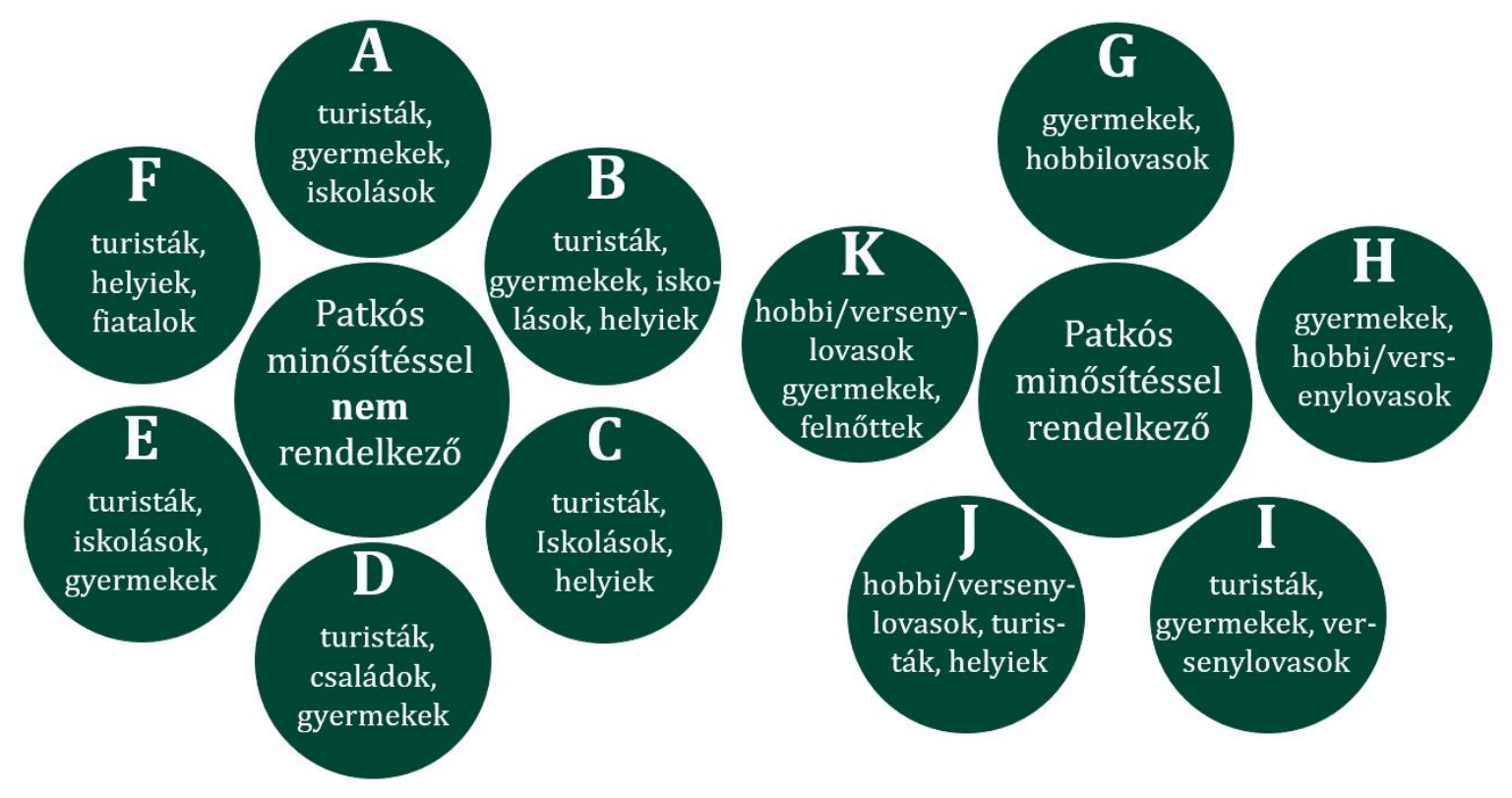

5. ábra: A lovas szolgáltatók által megcélzott célcsoportok

A minősítéssel még nem rendelkező létesítmények (vállalkozások) inkább a turistákat, gyermekeket, iskolás csoportokat célozzák meg, A minősített kategóriába tartozó vállalkozóknál a kifejezetten sportcélú lovaglással foglalkozó fogyasztók igényeinek kielégítése a fő cél, de mellettük jelen van a hobbylovasok csoportja is. Ez nem meglepő, hiszen a főbb minősítési szempontok sarkalatos pontjaként szerepel a fejlett lovas infrastruktúra, a kedvező környezetbeli adottságok, lovak ésszerű tartásával kapcsolatos tényezők, amelyek mind fontos feltételei a magas szintű lovassport űzésének.

A célcsoportok meghatározásán túl a vizsgálat tárgyát képezte a fogyasztók irányába nyújtott szolgáltatástípusok felmérése is. Különbséget tettünk a passzív és aktív szolgáltatások között. A passzív szolgáltatáshoz a lovas tudást nem igénylő szolgáltatási formákat soroltuk. Ezek célközössége az alkalmi látogatók (pl. turisták különböző csoportjai, a kiránduló iskolás osztályok), hiszen ez a réteg is piaci keresletet gerjeszt, s cél is ennek a rétegnek az elérése. Az aktív programkínálat elemei között, mely ahogy az nevéből is adódik lovas tudással rendelkező fogyasztókat céloz meg, s amely a legtöbb létesítményben nagyobb hangsúlyt kap, hiszen az aktív lovas programokkal stabil, visszatérő fogyasztói bázis kialakítása és megtartása válik lehetővé, mely egyben a létesítmények fenntartásának elengedhetetlen feltétele. A passzív kínálati elemek ezzel szemben a lovassport piac másik felének lefedésére és elérése szolgálnak, és melynek célközönsége inkább az olyan alkalmi látogatókat fogja egybe, mint például a turisták különböző csoportjai, illetve a kiránduló iskolás osztályok, akik esetleg nem rendelkeznek lovastudással. 
A mélyinterjúik alapján megállapítható, hogy a szolgáltatók döntő többsége nem csak maximális nyereség elérésének motivációjából alapította vállalkozását, a létesítmények minél szerteágazóbb programkínálata a szolgáltatások széles skálájának kihasználását teszik lehetővé. A mélyinterjúk eredménye szerint az aktív szolgáltatásoknál, illetve szolgáltatóknál a fogyasztói igények kielégítése a hobbilovasok és a versenylovasok igényeinek kielégítésére fókuszál. Ez különösen olyan szolgáltatóknál jelenik meg, akik nem rendelkeznek magasan fejlett lovas infrastruktúrával, a fenttartás érdekében azonban a lehető leggazdaságosabban kialakítható és fejleszthető kínálati elemeket igyekeznek felsorakoztatni.

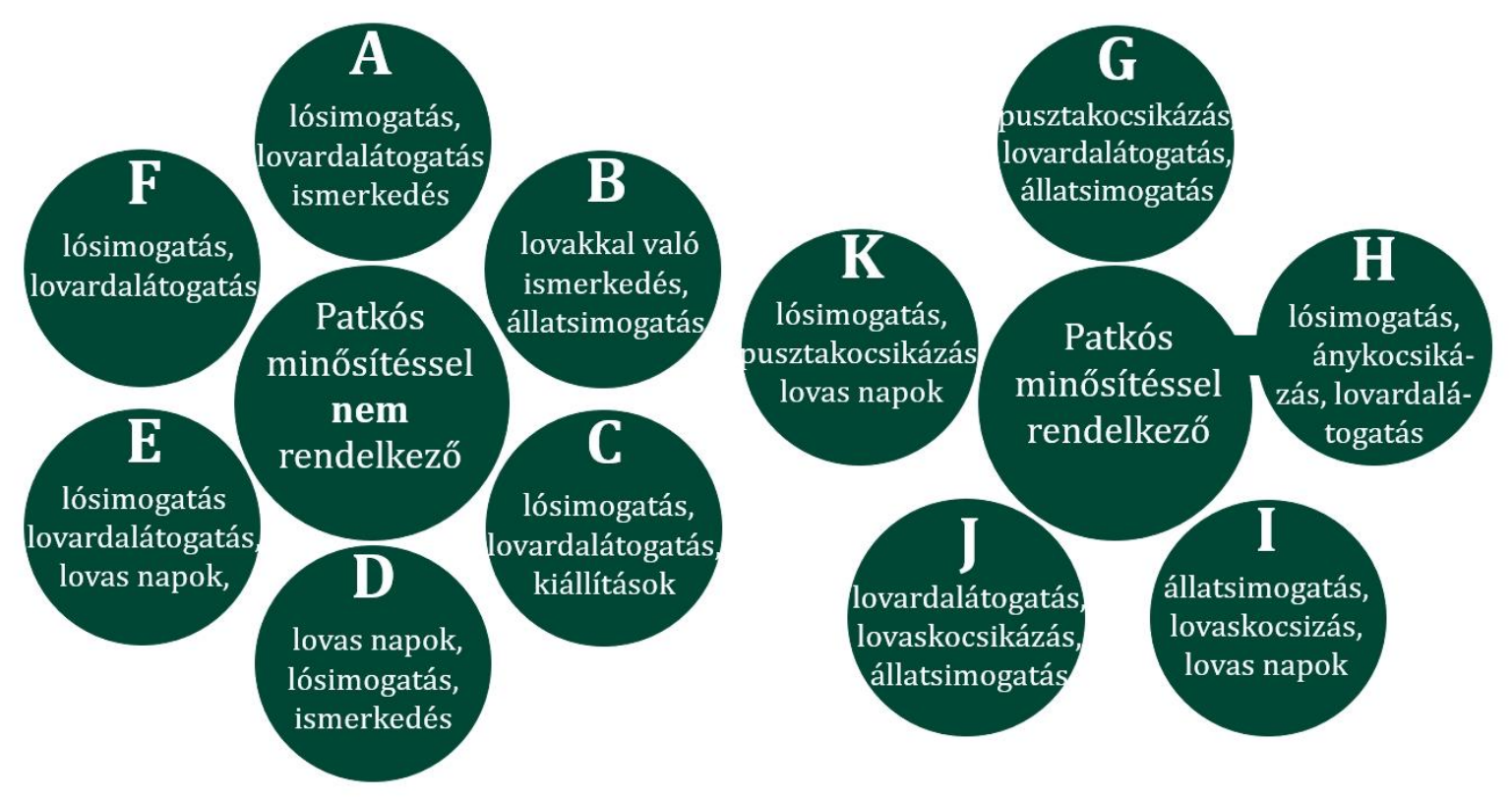

6. ábra: A vizsgált létesítmények passzív szolgáltatásai

A passzív kínálati elemeknél elsősorban a lovas programokkal és magával a lovakkal való ismerkedés kapja a legnagyobb hangsúlyt, mely mind a 11 megkérdezett létesítmény esetében elmondható. Ezzel nem csak egy jövőben visszatérő fogyasztói bázis kialakítása érhető el, de a lovassport hazai népszerűségének növelése is elérhető. Ilyen programként jeleni meg a lóhoz szoktatás, az állatok simogatása, lovardalátogatás, kiállítások és lovas táborok egyes elemei. Ugyan csak a passzív kínálati elemekhez sorolhatjuk az ökoturisztikai elemeket is.

Az aktív szolgáltatások kínálati elemei a minősülések eltérésének függvényében változtak, de alapvetően négy kategóriát lehetett felállítani. 


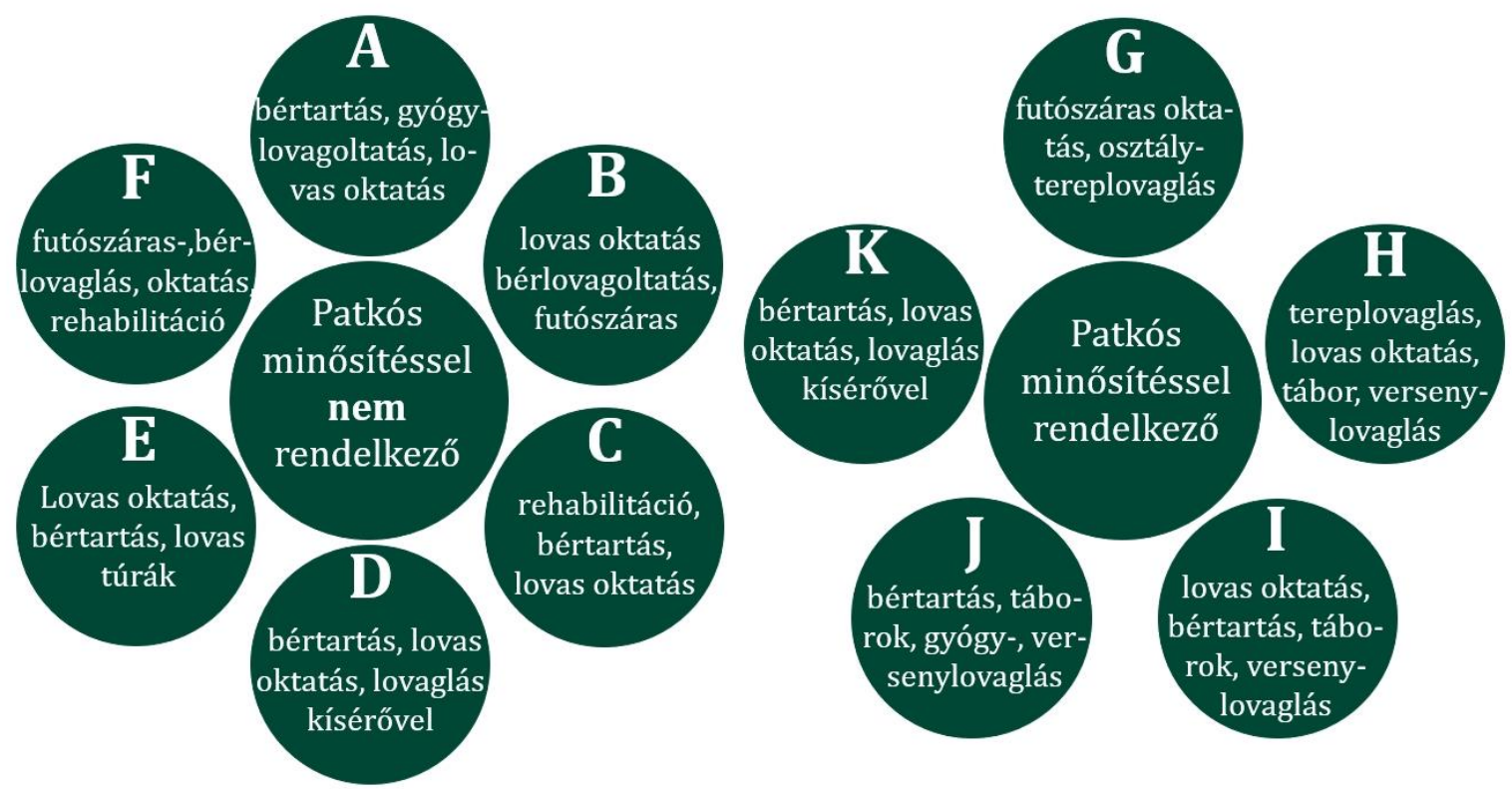

\section{7. ábra: A vizsgált létesítmények aktív szolgáltatásai}

1. Első csoportként a lovas sporttal és a lovaglással kapcsolatos oktatás különböző formáit lehetett beazonosítani, mint a lovagoltatás, lovas táborok, lovas oktatás, futószáras lovagoltatás karámokban. Ezzel a kezdő, lovassportok iránt érdeklődő fogyasztók igényeinek kielégítése a cél, $\mathrm{s}$ melyekkel inkább a fiatalabb korosztály, a gyermekek és iskolás csoportok megcélzása a fó szempont. A hobbilovasok utánpótlását jelenthetik a jövőben, hiszen ha megszeretik és elsajátítják a lovaglást, akkor a felnövekvő generáció a jövő lovasfogyasztóinak bázisát adhatja.

2. Ezt követi a lovaskísérő nélküli hobbilovaglás.

3. A következő kategória a lovassportokkal kapcsolatos kínálati elemeket tömörítette be, mint a lovas torna, a díjugratás, illetve a díjlovaglás.

4. És végül a terápiás célzattal nyújtott programelemek, mint a rehabilitáció, gyógylovaglás, mely az állatok terápiás felhasználásával az életminőség (életérzés) javításának egyik kiváló eszköze.

A passzív és az aktív szolgáltatások felmérése után azt is vizsgáltuk, milyen marketingkommunikációs eszközök felhasználásával kívánják elérni a szolgáltatók az általuk megcélozni kívánt célcsoportokat. Minősítettségtől függetlenül azt tapasztaljuk, hogy a lovas szolgáltatók esetében is háttérbe kerülnek a hagyományos marketingkommunikációs eszközök és helyette az online marketing (DM levelek, honlap, social media) eszközök kapnak elsőbbséget. Ezt napjainkban más területe-ket vizsgáló szakirodalmak is megerősítenek [21][31][1][20][7].

A fogyasztói preferenciák felmérésének értékelése során nyilvánvalóvá vált, hogy a legnépszerúbb szolgáltatások közé tartozik a bértartás és a bérlovagoltatás (11 vállalkozásból 7 esetében). Jelentős fogyasztói kereslet van a gyermek és iskoláscsoportoknak szervezett lovagoltatások és lovas oktatások terén. A minősített létesítmények között megjelent a puszta- és pusztakocsikázás is. Ez egyfajta átmenetet képez az aktív és passzív szolgáltatás típusok közt, hiszen konkrét lovas ismeretek meglétét nem feltételezi, azonban mégis remek bekapcsolódási lehetőséget teremt, az aktív lovas tevékenységek közé. 
A legnagyobb részvételt indukáló lovasszolgáltatásoknál a gyermekeknek szervezett programok, a lovasoktatás és a lovas táborok emelkedtek ki.

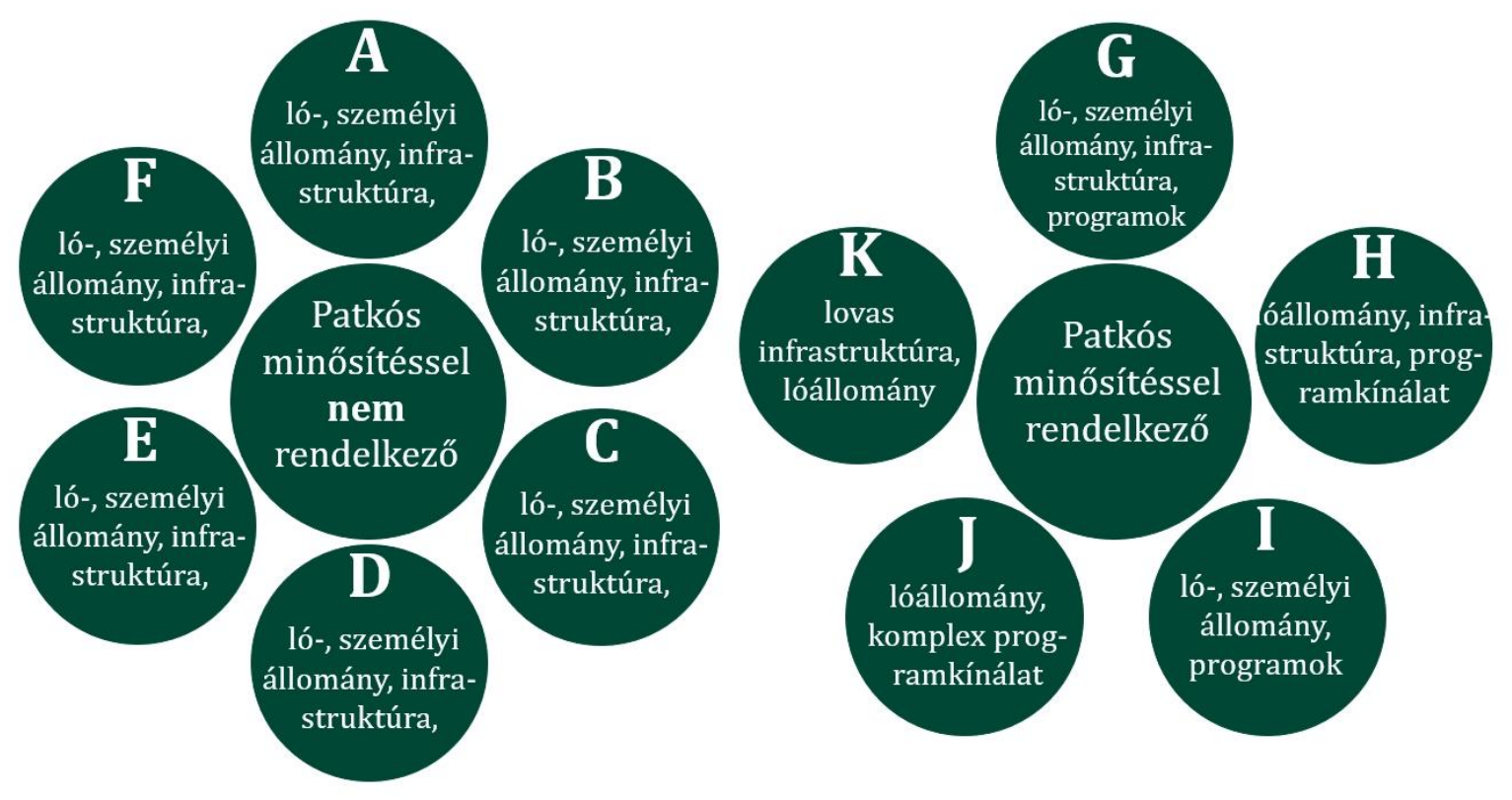

\section{8. ábra: A vizsgált létesítmények fejleszteni kívánt területei}

Mindegyik lovas szolgáltató fejlesztési terveiben az infrastruktúra és humánerőforrás azon belül is a lovasállomány bővítése, fejlesztése egyaránt megjelenik. A patkós minősítéssel nem rendelkező lovas szolgáltatók a jövő útjaként egyértelműen a minőség fejlesztését jelölték meg, míg a magas minőséggel rendelkező szolgáltatók a komplex programkínálat biztosítása érdekében történő kínálatbővítést, termékdiverzifikációt állították középpontba.

\section{Konklúzió}

A lovas szolgáltatók tipológiai értelmezése segítheti a szolgáltatók működési hátterének feltérképzését és fejlesztési javaslatok megfogalmazását, valamint segítheti a kormányzati szerveket a támogatások felosztásában.

A lovas szolgáltatások az elmúlt évtizedekben jelentős fejlesztéseken mentek keresztül, aminek során a minőségi szolgáltatásfejlesztés és a fedett lovardák építése előnyt élvezett, Ez Magyarország „lovas nemzet" imázsát erősítette és a szolgáltatások nemzetközi versenyképességét is javította.

A patkós minősítés és a minősített szolgáltatók garanciát jelentenek a fogyasztóknak, a minőségi kínálati elemek biztosításában és magas vendégelégedettséget eredményezhet, melyet nemzet-közi szakirodalmak is megerősítenek [8][28]. A komplex szolgáltatások is megjelennek a patkós minősítettséggel rendelkező lovas szolgáltatóknál. A jelenleg még nem minősített szolgáltatók többsége a minőség-fejlesztést, a kínálatbővítést nevesítette e terveiben, mely a hazai versenyképességüket javíthatja. Az Észak-alföldi régió lovasturisztikai adottságai és jelenlegi kínálata versenyképes a hazai és nemzetközi piacon is, mely igényli a folyamatos extenzív és intenzív fejlesztést 
egyaránt. A sport és szabadidőgazdaság, valamint turizmus területét érintő kutatások igazolják, hogy a minőségi termékek és szolgáltatások iránt nő a kereslet, valamint a minőség a vásárlói- vagy vendégelégedettsége pozitívan befolyásolja [30][11][27][3][6][10][9].

\section{A publikáció elkészítését az EFOP-3.6.2-16-2017-00003 számú projekt támogatta. A projekt az Európai Unió támogatásával, az Európai Szociális Alap társfinanszírozásával valósult meg.}

\section{Hivatkozások}

[1] K. Alexandris - K. Kaplanidou (2014) Marketing sport event tourism: Sport tourist behaviors and destination provisions. Sport Marketing Quarterly. 23 (3) pp. 125-127.

[2] AZ ÉSZAK-ALFÖLDI RÉGIÓ STRATÉGIAI PROGRAMJA 2007-2013 http://www.terport.hu/webfm_send/642.

[3] É. J. Bartha - A. Müller - É. Bácsné Bába (2018) A Fitnesz fogyasztók sportlétesítmény-választását befolyásoló legfóbb szempontok alakulása életkor szerint. Selye E-studies 9 (1) pp. 4-12. Paper: http://old.e-studies.ujs.sk/hu/cimlap/cat_view/1-e-studieshu.html?limit=5\&limitstart=0\&order=date\&dir=DESC

[4] P. Béki - T. Vágó - D. Lasztovicza (2013): The present of equine tourism in Hungary in reflection to an empirical research. APSTRACT: Applied Studies in Agribusiness and Commerce, 7(10332016-84197), 19.

[5] A. Borbély - A. Müller A. (2015) Sport és turizmus. Debrecen, Magyarország : Campus Kiadó, 110 p. ISBN: 9789639822368

[6] É. Bácsné Bába - C. Pfau - K. Dajnoki - A. Müller (2018) Examining the quality parameters of sports services.In: Jaromír, Šimonek; Beáta, Dobay (szerk.) Sport science in motion : proceedings from the scientific conference. Športová veda v pohybe: recenzovaný zborník vedeckých a odborných prác $\mathrm{z}$ konferencie. Mozgásban a sporttudomány: válogatott tanulmányok a konferenciáról.Komárno, Szlovákia : Univerzita J. Selyeho, pp. 236-243. , 8 p.

[7] G. Ráthonyi - K. Ráthonyi-Odor - L. Várallyai - Sz. Botos (2016) Influence of social media on holiday travel planning. Journal of Ecoagrotourism. 12 (1) pp. 57-62.

[8] G. Helgadóttir - I. Sigurðardóttir (2008) Horse-based tourism: Community, quality and disinterest in economic value. Scandinavian Journal of Hospitality and Tourism. 8 (2) pp. 105-121.

[9] P. Hidvégi - M. Bíró - A. Lenténé Puskás - J. Pucsok - A. Tatár - K. Bárdos (2019) Wellnes szolgáltatások minősége az Észak-alföldi régióban. In: Bácsné, Bába Éva; Müller, Anetta (szerk.) "Mozgással az egészségért" A fizikai aktivitás jelentősége a jövő munkavállalóinak egészségmegőrzésében: Nemzetközi Konferencia és Workshop: Válogatott tanulmánykötet = "Movement for health" The importance of physical activity in health protection of future workers: International Conference and Workshop: Proceedings from the International Conference and Workshop. Debrecen, Magyarország: Debreceni Egyetem, pp. 189-197. , 9 p.

[10] K. V. Mórik - É. Bácsné Bába - A. Müller - G. G. Ráthonyi - A. Molnár (2019) The appearance of product innovation in the life of a Hungarian SMEs in the global market of sporting goods implications from a research. GeoSort for Society 10 (1) pp. 25-38. , 14 p.

[11] Y. J. Ko - D. L. Pastore (2005) A Hierarchial Model of Service Quality for the Recreational Sport Industry. Sport Marketing Quarterly. 14(2).

[12] E. Könyves - A. Müller (2001) Szabadidős programok a falusi turizmusban. Szaktudás Kiadó Ház, Budapest .185.p. 
[13] E. Könyves - A. Müller (2007) Az Észak-alföldi régió Turizmusfejlesztési stratégiája 2007-2013. In: Fejlesztés és képzés a turizmusban. II. Országos Turisztikai Konferencia tudományos közleményei. (cd) 2007. Fejlesztés és képzés a turizmusban. PTE, Magyarország, Pécs.

[14] E. Könyves - E. Suta (2009) The importance of equestrian tourism enterprises in tourism destination management in Hungary. APSTRACT: Applied Studies in Agribusiness and Commerce. 4(1033-2016-83944), 25.

[15] B. Lane (2009) Rural tourism: An overview. The SAGE handbook of tourism studies. pp. 354-370.

[16] E. Lóska (2016) Lovas turisztikai Térkép. Az észak-alföldi régió lovasturisztikai adottságai. Lovasélet. 2016. márc. 2. rész. pp. 22-25.

[17] J. Lóska (2001) Az Észak-magyarországi és Észak-alföldi régió lovas turizmusának helyzete és kibontakozásának

lehetôségei, http://www.logyogyasz.hu/_data/VFS_a2b2460a47cc158bac7680d17412aa3f.pdf

[18] Lovas Turizmus Termékfejlesztési 2007-2013, http://www.logyogyasz.hu/_data/VFS_c8c9c84eaaf138481b7f851359d7edf4.pdf

[19] G. Michalkó - I. Vízi (2002) A rekreáció szerepe az aktív turizmusban. Magyar Sporttudományi Szemle. 3-4. pp. 19-23.

[20] A. Müller - E. J. Boda - G. Ráthonyi - K. Ráthonyi-Odor - B. Barcsák - E. Könyves - M. Bíró - B. Dobay - E. Bendíkova (2016) Analysis of the cavebath of Miskolctapolca's brand elements and guests satisfaction. APSTRACT - Applies Studies in Agribusiness and Commerce. 10 (4-5) pp. 155-160.

[21] A. Müller - R. Szabó (2009) Analysis of Agárd, Komárom and Papa's Thermal bath, According the Guest's satisfaction. Acta Academiae Paedagogicae Agriensis Nova Series: Sectio Sport. 36. pp. 89101.

[22] A. Németh (2004) Lovasturizmus Magyarországon. GAZDÁLKODÁS: Scientific Journal on Agricultural Economics, 48(80-2016-637), 95.

[23] C. Ollenburg (2005) Worldwide structure of the equestrian tourism sector. Journal of Ecotourism. 4 (1) pp. 47-55.

[24] B. Ormos - C. S. Obádovics (2013) A ló és a vidékfejlesztés, különös tekintettel a lovasturizmus hatására. Konkoly-Gyuró É. et al. (szerk.): Tájtudomány-Tájtervezés. V. Magyar Tájökológiai Konferencia. Konferencia kiadvány, Nyugat-magyarországi Egyetem Kiadó, Sopron. pp. 221-227.

[25] S. Z. Rácz (2008) A lovasturizmus, mint a területi fejlődés egyik sajátos szegmense. Szónokyné Ancsin G.(szerk.): Magyarok a Kárpát-medencében. Tudományos nemzetközi konferencia, Szeged. pp. 514-526.

[26] A. Rudiné Mezei - J. Posta - S. Mihók (2013) Hazai és külföldi tenyésztésú lovak teljesítményének összehasonlítása a díjugrató sportban elért eredmények alapján. Állattenyésztés és Takarmányozás. 62 (1) pp. 57-69.

[27] D. J. Shonk - P. Chelladurai (2008) Service quality, satisfaction, and intent to return in event sport tourism. Journal of sport management. 22 (5) pp. 587-602.

[28] I. Sigurðardóttir - G. Helgadóttir (2015) Riding high: Quality and customer satisfaction in equestrian tourism in Iceland. Scandinavian Journal of Hospitality and Tourism. 15 (1-2) pp. 105121.

[29] B. Tapolcsányi (2014) A Nemzeti Vágta turisztikai jelentôsége hazánkban. E-CONOM. 4 (1) pp. 40-51. 
International Journal of Engineering and Management Sciences (IJEMS) Vol. 4. (2019). No. 3

DOI: 10.21791/IJEMS.2019.3.8.

[30] H. M. Westerbeek - D. Shilbury (2003) A conceptual model for sport services marketing research: integrating quality, value and satisfaction. International Journal of Sports Marketing and Sponsorship. 5 (1) pp. 3-23.

[31] C. Witkemper - C. H. Lim - A. Waldburger (2012) Social media and sports marketing: Examining the motivations and constraints of Twitter users. Sport Marketing Quarterly. 21 (3). 